\title{
Three new species of Oligaphorurini (Collembola: Onychiuridae) without anal spines from European Part of Russia
}

\section{Три новых вида Oligaphorurini (Collembola: Onychiuridae) без анальных шипов из Европейской части России}

\author{
Yu. Shvejonkova ${ }^{1} \&$ M. Potapov ${ }^{2}$ \\ Ю. Швеенкова ${ }^{1}$, М. Потапов ${ }^{2}$
}

\footnotetext{
${ }^{1}$ State Nature Reserve "Privolzhskaya Lesostep”, Penza 440031, Okruzhnaya 12a, Russia. E-mail: jushv@mail.ru.

${ }^{1}$ Государственный природный заповедник “Приволжская лесостепь”, ул. Окружная, д. 12a, Пенза 440031, Россия.

${ }^{2}$ Moscow State Pedagogical University, Kibalchich str. 6, build. 5, Moscow 129164, Russia. E-mail: mpnk@orc.ru.

${ }^{2}$ Московский педагогический государственный университет, ул. Кибальчича, д. 6, корп. 5, Москва 129164, Россия.
}

KEY WORDS: Collembola, Onychiuridae, Oligaphorurini, anal spines, new species, Russia.

КЛЮЧЕВЫЕ СЛОВА: Collembola, Onychiuridae, Oligaphorurini, анальные шипы, новые виды, Россия.

\begin{abstract}
The paper provides the descriptions of Micraphorura stojkoae, Oligaphorura kremenitsai and Oligaphorura humicola spp.n. belonging to tribe Oligaphorurini and lacking anal spines. Absence of anal spines as a main taxonomical character of Archaphorura Bagnall, 1949 is revaluated. Genera Oligaphorura Bagnall, 1949 and Micraphorura Bagnall, 1949 are redefined and the status of Archaphorura and its type species are discussed. The value of labial palp is discussed.
\end{abstract}

РЕЗЮМЕ. В работе приведены описания Micraphorura stojkoae, Oligaphorura kremenitsai и Oligaphorura humicola spp.n., относящихся к трибе Oligaphorurini и не имеющих анальных шипов. Критически оценивается значение анальных шипов как основного признака Archaphorura Bagnall, 1949. Для родов Oligaphorura Bagnall, 1949 и Micraphorura Bagnall, 1949 приводятся новые диагнозы, обсуждается статус рода Archaphorura и его типового вида. Обсуждается значение строения нижнегубного щупика для диагноза родов трибы Oligaphorurini.

\section{Introduction}

In the course of our investigation of deep soil layers of chernozem soils of the East European Plain we collected three species of the tribe Oligaphorurini without anal spines. First they were formally identified as the members of the genus Archaphorura Bagnall, 1949. So far this small taxon was readily identified by the absence of anal spines and its taxonomical position remained the least disputable [Weiner, 1996; Pomorski, 1998; Fjellberg, 1998]. One of the new species under study, however, shared several significant characters with Micraphorura Bagnall, 1949, while the other two

Printed in 2012 were much closer to the genus Oligaphorura Bagnall, 1949 than to $A$. serratotuberculata (Stach, 1933), the type species of Archaphorura. These observations led us to describe these forms of Oligaphorurini as new species of Micraphorura and Oligaphorura, traditionally accepted as "spined" genera, re-estimate the value of anal spines, and update diagnoses of these two genera. Type materials of newly described species are kept in Moscow State Pedagogical University.

ABBREVIATIONS: Th. - thoracic segment; $A b d$. abdominal segment; Ant. — antennal segment; $m s$ microsensillum/a; PAO — postantennal organ; s sensillum/a; pso — pseudocellus/pseudocelli.

\section{Generic taxonomy of the tribe Oligaphorurini}

The taxonomical value of anal spines in the family

Bagnall's generic division [Bagnall, 1948, 1949] of the Onychiuridae and, particularly, subfamily Oligaphorurinae (accepted as tribe Oligaphorurini now), was based on many characters of different nature which all did not combine a strict logic pattern. Subsequently, Weiner [1996] and Pomorski [1996, 1998] described new genera and at that they mostly kept and redefined Bagnall's taxa using more reliable characters. Like in Bagnall's approach, in their generic taxonomical systems the presence/absence of anal spines was of great taxonomic value. During last decade, it was, however, shown that "spined" and "aspined" congeners can combine the genera of Onychiurinae, as Thalassaphorura Bagnall, 1949, Vibronychiurus Pomorski, 1998, Sensillonyhiurus Pomorski et Sveenkova, 2006[Sun et al., 2010; Pomorski, 2006; Pomorski \& Sveenkova, 2006; Babenko et al., 2011]. If formally present, the size of spines may vary considerably in a genus, from strong and thick to tiny and seta-like, depending on species (for instance, in Micronychiurus Bagnall, 1949). The similar trend appears in 
taxonomy of family Isotomidae - anal spines get recently less value in the definitions of genera [Fjellberg \& Potapov, 1998; Potapov et al., 2006, 2010].

Current generic taxonomy of tribe Oligaphorurini

In the tribe, four genera are accepted by the most authors: Chribellphorura Weiner, 1996, Archaphorura Bagnall, 1949, Micraphorura, and Oligaphorura. The first genus appears rather specific due to two very rare characters: an apical vesicle on antennae and clavate dorso-distal setae on tibiotarsi. Archaphorura is readily defined by the absence of anal spines and subapical position of antennal organ III which are the unique characters for the tribe. The independence of Micraphorura and Oligaphorura is supported by furcal rudiment, considered to be one of the most important characters to discriminate between genera [Weiner, 1996, Pomorski, 1998]. According to these authors the area behind cuticular furrow (furcal rudiment) has 4 "dental" setae in two rows $(2+2)$ in Oligaphorura, and $2(1+1)$ in one row in Micraphorura. Such a division is validated by a study of first instar larvas [Pomorski, 1996]. Archaphorura serratotuberculata has "two rows" pattern at the cuticular furrow like in Oligaphorura. The firth genus Dimorphaphorura Bagnall, 1949 was recovered by Weiner [1996] as a monotypic taxon (type species: Dimorphaphorura differens Bagnall, 1949) and is characterized by a finely granulated area (instead furcal furrow), 4 (vs. 2 in Micraphorura) "dental" setae in one row behind it, and 1 (vs. 2 in Micraphorura) transversal row of setae in median part of so-called "manubrial area". So far, in Micraphorura, at least two species (M. steposa Kaprus et al., 2002 and M. eremia Kaprus et al., 2002) are described with furcal area outwardly identical with that of Dimorphaphorura: furca entirely disappears forming a field of finer granulation, a pair of anterior manubrial setae $(m a)$ are located almost at the level with $1+1$ dental setae making an expression of one regular row of 4 dental setae, and only posterior row ( $\mathrm{mp}$ ) of manubrial setae present (medial row $m m$ is lost). In addition, according to our data on other species this area is often disturbed by asymmetry masking the real number of the rows. So far the independence of Dimorphaphorura calls for further ground. We suppose, several lines of Oligaphorurini independently undergo the reduction of furcal area, including furrow and number of manurial setae, as well as the reduction of chaetotaxy of body and tibiotarsi, resulting in low value of these characters at level of generic taxonomy of Oligaphorurini.

Species of Oligaphorurini without anal spines and redefinition of Oligaphorura and Micraphorura

Taking into account the essential dissimilarity between three new "aspined" species and A. serratotuberculata and their similarity to particular species of "spined" genera (see the Discussion part to M. stojkae sp.n. and $O$. kremenitsai sp.n.) we propose new tentative diagnoses of two central genera of tribe, Oligaphorura and Micraphorura, which, in our understanding, may include species without anal spines.

Genus Oligaphorura Bagnall, 1949 (type species: Lipura groenlandica Tullberg, 1876). Oligaphorurini with or (more rarely) without anal spines. Abd. V and VI well separated. Anterior part of head with $3+3$ or (more rarely) $4+4$ pseudocelli, in the last case 3 more medial pseudocelli arranged longitudinally. Subapical whorl of tibiotarsi with 11 or fewer setae. Furcal rudiment has 4 "dental" setae in two transversal rows. Furcal rudiment in form of cuticular furrow or field of finer granulation. Number of rows of manubrial setae varies.

Genus Micraphorura Bagnall, 1949 (type species: Aphorura absoloni Boerner, 1901). Oligaphorurini with or (more rarely) without anal spines. Abd. V and VI well separated. Anterior part of head with $3+3$ pseudocelli. Subapical whorl of tibiotarsi with 11 or fewer setae. Furcal rudiment has 2 or 4 "dental" setae in one transversal row. Furcal rudiment in form of cuticular furrow or field of finer granulation. Number of rows of manubrial setae varies.

The status of Archaphorura and its type species

The exact definition of $A$. serratotuberculata s.str. is obscure. According to first description [Stach, 1933], A.serratotuberculata has 32/133/33442 dorsal pseudocelli on body and 1 ventral pseudocellus on head. Pomorski [1998] and Fjellberg [1998] proposed the dorsal formulas as 32/122/33343 and 33/133/33344, respectively, 2 pseudocelli were indicated for ventral side of the head by the former author. Our individuals from several localities of the East European Plain (Moscow and Vladimir areas, coll. N.Kuznetsova, A.Chernov, V.Romanov) show 32/133/33343, and ventrally 2 pso on head. Weiner [1996] mentioned several undescribed species of Archaphorura differing at least in number of pseudocelli on Abd. IV and V and microsensilla on Th.III (present/absent). Nevertheless, so far the known descriptions of $A$. serratotuberculata are in relative agreement sharing several rare characters: subapical position of antennal organ III covering microsensillum, fusion of two last abdominal segments [in Fjellberg, 1998 as "abd.5-6 strongly rounded in profile"], and full set (11) of setae in subapical whorl of tibiotarsi (vs. 6-7 in "aspined" species from our material).

\section{Labial palp}

In three new species the labial palp was studied in details (Figs 9, 17, 28). After Fjellberg [1998/99] labial types of Oligaphorurini support the generic status of $A r$ chaphorura (since labial type $A B C$ was only observed in $A$. serratotuberculata, Fig. 31) while do not support the Micraphorura/Oligaphorura division - labium of Micraphorura absoloni (Boerner, 1901) is of type $A C$ (Fig. 33), labium of the genus Oligaphorura varies from type $A C$ in the type species (Fig. 32) and O.sabulosa Babenko, 2004 to type $A$ in other species under study. The condition of papillae found in $M$. stojkae sp.n. is similar to $A$. serratotuberculata (type $A B C$, Fig. 9) in spite of these two species show different furcal field patterns ("one row" vs. "two rows"). O. humicola sp.n. and $O$. kremenitsae sp.n. show "two rows" pattern like in A. serratotuberculata but well differ from the latter, as well as from "spined" members of the genus Oligaphorura, by the unique labial type 
$(A B D)$. In addition, labial palp of these two edaphic species undergoes the same reduction supporting their close relation: papilla $C$ is low and its terminal sensillum is short, papilla $E$ absent (or it is at least undistinguishable from guards nearby), all guards are shorter than in other Oligaphorurini with known labium (Figs 17, 28).

\section{Descriptions of new species}

Micraphorura stojkoae Shvejonkova et Potapov, sp.n. Figs 1-11.

TYPE MATERIAL: Holotype: $\sigma^{x}$, Russia (European part), Middle Volga River Basin, Penza district, Ostrovtsovskiy plot of "Privolzhskaya Lesostep" Reserve, deciduous forest (Padus avium), soil $(0-10 \mathrm{~cm}), 6 . V .2000$, leg. Yu. Shvejonkova. Paratypes: $2 \bigcirc^{7} \sigma^{\top}, 1$, ibidem.
OTHER MATERIAL: ,, Penza district, Kuncherovskiy plot of "Privolzhskaya Lesostep" Reserve, steppe, 10.V.2008, leg. M. Potapov; 2우, Russia (European part), Lipetsk district, «Galich’ya Gora» Reserve, near Donskoye, sandy bank of Don River, 10.IX.2008, leg. M. Potapov; $2 O^{7} \sigma^{7}$, Russia (European part), Samara district, the Samara Bend National Park, broad-leaved forest (maple, linden), soil, 2.05.11, leg. Yu. Shvejonkova; $1 \mathrm{O}^{7}$, the Samara Bend National Park, Shirjaevo, steppe on the slope, 13.06.11, leg. Yu. Shvejonkova.

DESCRIPTION. Length of body $0.4-0.55 \mathrm{~mm}$. Body of normal shape, without anal spines. Length of antennae as about $4 / 5$ of head. Furcal rudiment appears field with thinner granulation with $1+1$ setae behind, without cuticular furrow. Granulation of body regular, coarser around dorsal pso, each pso with 11-14 granules.

Ant. IV with subapical organite (Fig. 8). Lateral $m s$ above antennal organ III, in first row of setae. Antennal organ III in normal position, with 5 papillae, 2 sensory rods, 2 clubs (external large, with wrinkles, internal smaller, finely granulated), 5

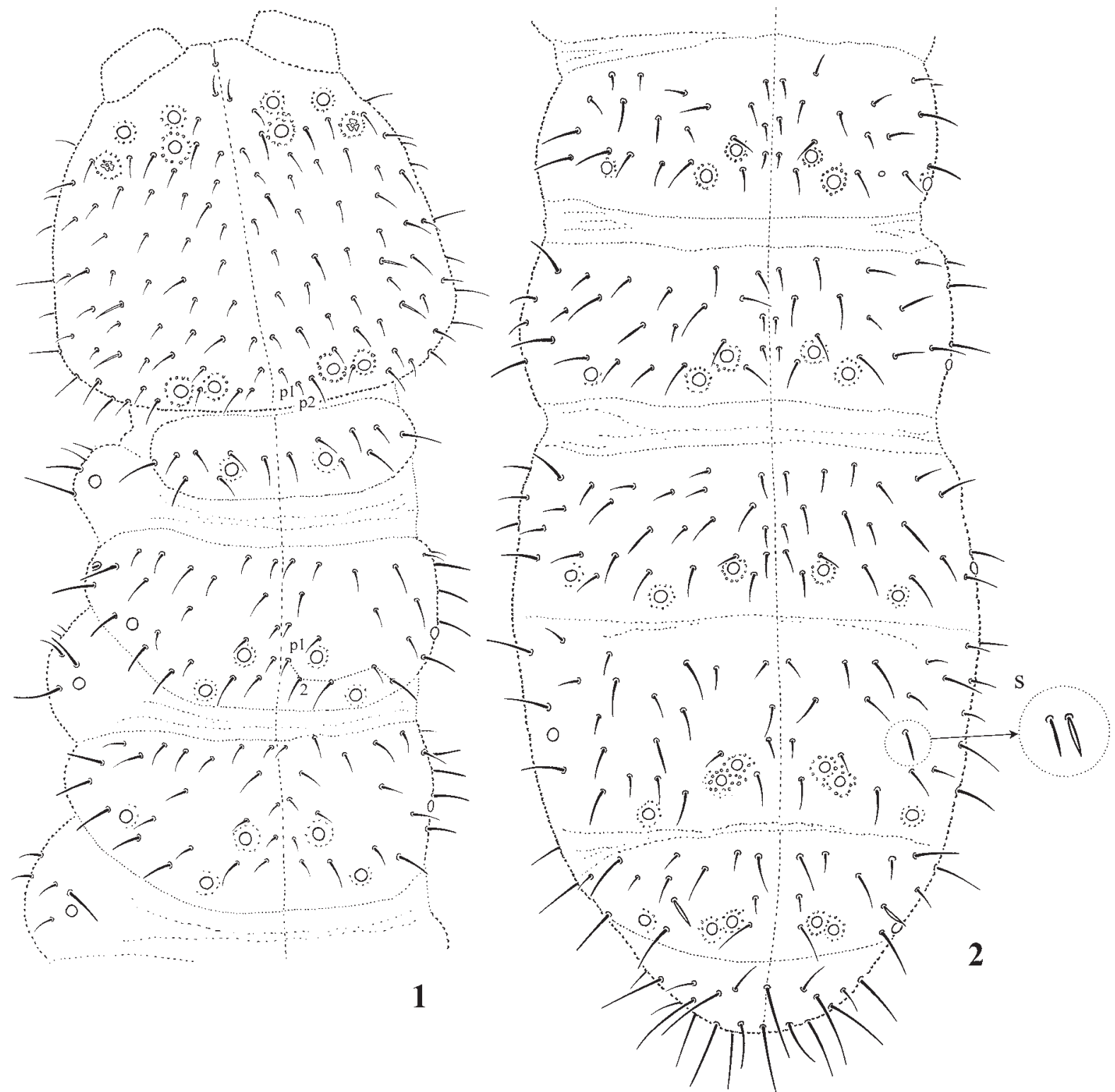

Figs 1-2. Micraphorura stojkae sp.n., dorsal chaetotaxy: 1 - head and thorax; 2 - abdomen; $s$ - sensillum, $p 1, p 2-$ setae of $p$-row. Рис. 1-2. Micraphorura stojkae sp.n., хетотаксия дорсальной поверхности: 1 - голова и грудь; 2 - брюшко; $s$ - сенсилла, $p 1, p 2-$ хеты $p$-ряда. 
guard setae (Fig. 7). Ms of Ant. III in lateral position, under antennal organ. Ant. I and II with 8 and 13-14 setae, respectively. Labial palp as common for subfamily: 6 proximal setae, papilla $E$ present, low, 10 guards ( 6 large and curved and 4 small and erect), terminal sensilla of papillae $A-C$ thickened ( $A B C$ type), sensillum $C$ weaker than $A$ and $B$ (Fig. 9). Maxillary palp simple, two sublobal hairs. PAO small, with three-lobed vesicle.

Pseudocellar formula dorsally 32/133/33343, ventrally $2 / 000 / 0000$. Parapseudocelli indistinct, at least $1+1$ venrally on $A b d$. IV. Each subcoxa with 1 pso.
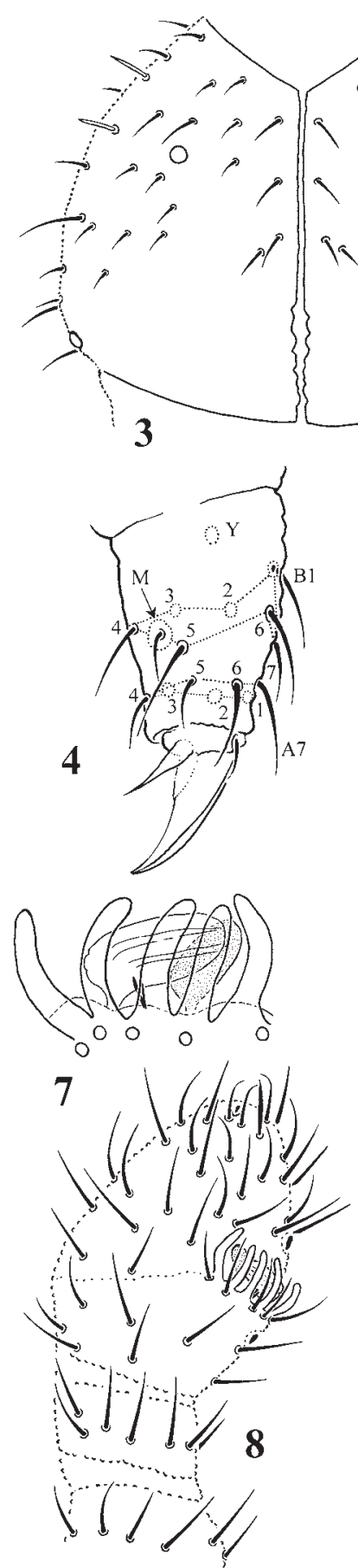

\section{5}
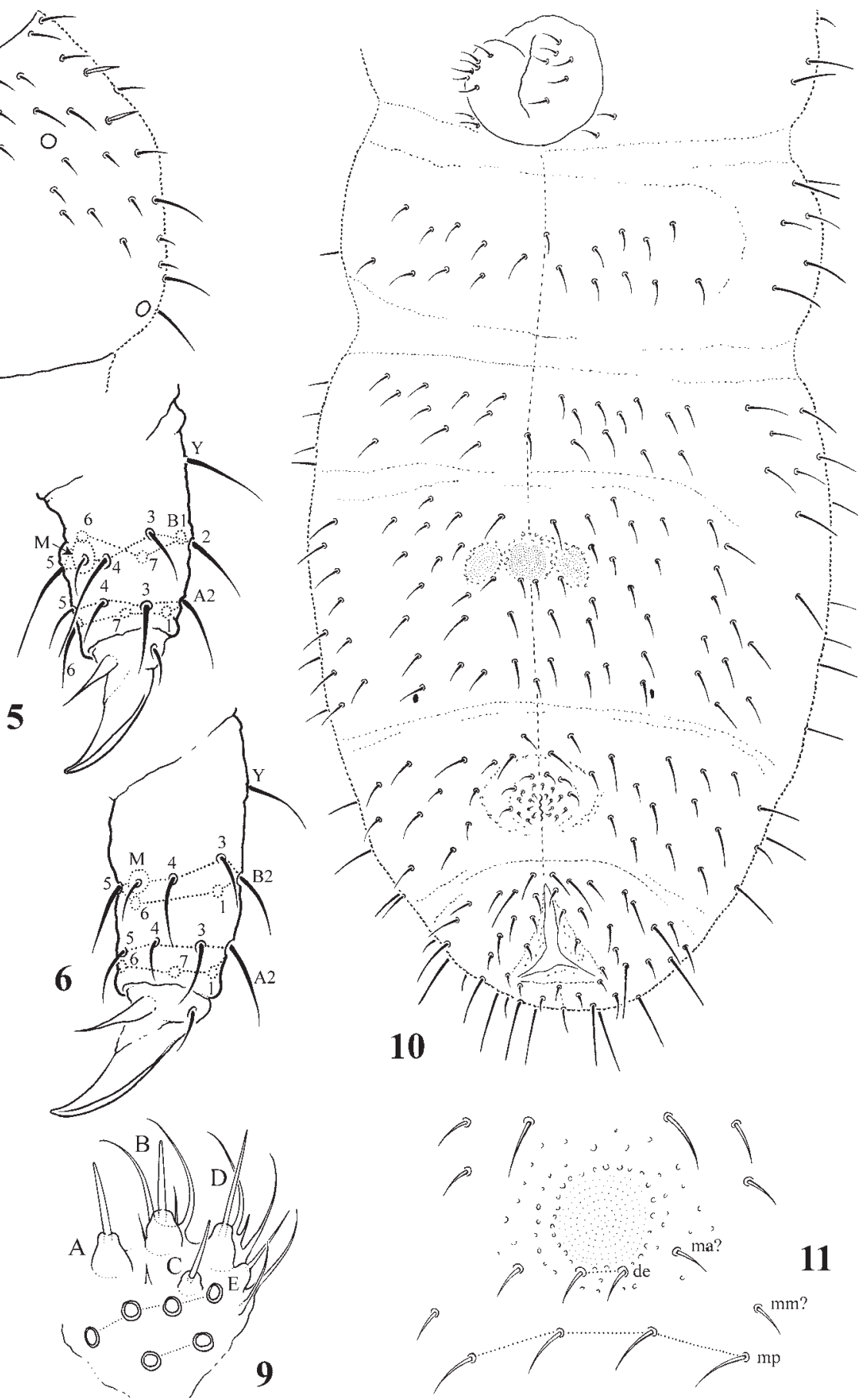

Figs 3-11. Micraphorura stojkae sp.n.: 3 - ventral chaetotaxy of head; 4-6 - tibiotarsi of leg I (4), II (5), and III (6); 7 - antennal organ; 8 - antenna, dorsal view; 9 - labial palp (proximal setae shown as sockets); 10 - ventral chaetotaxy of abdomen; 11 - furcal area; $A, B, C, D, E$ - papillae of labial palp; $B 1-7, A 1-7, Y, M$ - notation of tibiotarsal setae, $m a, m m, m p$ - manubrial setae, de - dental setae.

Рис. 3-11. Micraphorura stojkae sp.n.: 3 - хетотаксия вентральной поверхности головы; 4-6 - тибиотарзусы первой (4), второй (5) и третьей (6) пар ног; 7 - антеннальный орган; 8 - усик, вид со спинной поверхности; 9 - нижнегубной щупик (проксимальные щетинки показаны в виде оснований); 10 - хетотаксия брюшной поверхности брюшка; 11 - поле прыгательной вилки; $A, B, C, D, E-$ выросты нижнегубного щупика; $B 1-7, A 1-7, Y, M$ - обозначения хет голенелапки, ma, $m m, m p-$ манубриальные хеты, de - дентальные хеты. 
Dorsal chaetotaxy as shown in Figs 1-2, poorly differentiated to macro- and microsetae. Sensilla indistinct, with dorsal formula $2 / 000 / 00001$, head ventrally with $2+2$ sensilla. Without distinct sensilla on lower subcoxa of all legs. On head seta $d 0$ absent, in posterior row of setae seta $p 1$ in front of $p 2$. On Th. II $-A b d$. III seta $p 1$ in front of $p 2$. On $A b d$. VI $a 0$ subequal to $a 2$, $a 12 / 5$ as long as $a 0$. Lateral $m s$ present only on Th. II. Upper subcoxa I-III with 4, 5, 5 setae, respectively. Ventral chaetotaxy as shown in Figs 3, 10-11. Furca reduced to three finely granulated area, lateral parts often absent, size of median one varies in size, with 2 "dental" setae arranged in one transversal row (Figs 10-11), with only one row of manubrial setae in median area. Ventral tube with $6+6$ setae and $2+2$ setae at its base (Fig. 10). Thoracic sternites II and III with $1+1$ setae each.

Claw without teeth, empodial appendage with weak basal lamella, 3/4 as long as inner edge of claw. Tibiotarsi with 16 ,
16,15 setae, with 7 ones in distal whorls (Figs 4-6). All setae of rows $A$ and $B$ present $(A 1-7, B 1-7)$, seta $B 7$ on leg III absent, $T$-setae absent, $M$ and $Y$ setae present on all legs.

Males present, without ventral organ.

DISCUSSION. The new species mostly resembles $M$. irinae Thibaud et Taraschuk, 1997 (Ukraine) and M. pieninensis Weiner, 1988 (Poland, Ukrain) by number of dorsal pseudocelli, chaetotaxy of antennae and antennal organ, empodial appendage and others characters. Apart from the absence of anal spines (present in two mentioned species), these species differ in number of tibiotarsal setae in distal whorl (7 vs. 9 and 11, respectively) and pseudocelli on subcoxae (present vs. absent in M. irinae). M. pieninensis has less reduced furcal area: two (vs. one M. stojkoae sp.n.) rows of manubrial setae and cuticular furrow present (vs. absent). M. stojkoae sp.n. differs from $A$. serratotuberculata with many significant char-

Table. Differentiating characters of Oligaphorurini without anal spines or having 4 antennal pso.

Таблица. Отличительные признаки Oligaphorurini без анальных шипов или имеющих 4 антеннальных ложных глазка.

\begin{tabular}{|c|c|c|c|c|c|c|c|}
\hline & 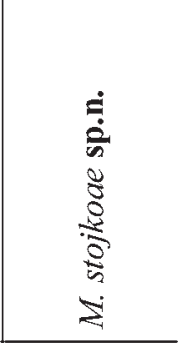 & 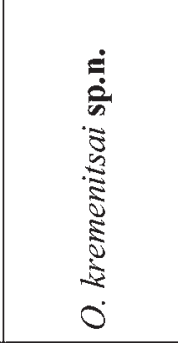 & 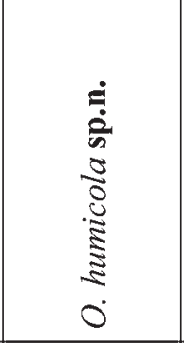 & 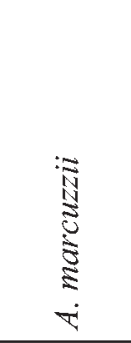 & 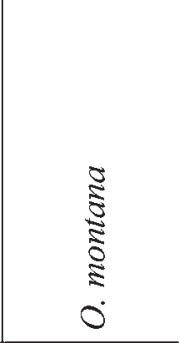 & $\begin{array}{l}\frac{5}{5} \\
\frac{5}{0} \\
\frac{8}{8} \\
+\end{array}$ & 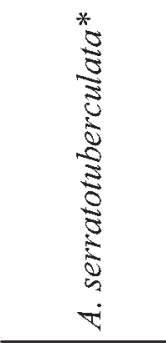 \\
\hline Dental setae & $\begin{array}{c}1+1 \text { in one } \\
\text { row }\end{array}$ & $\begin{array}{c}2+2 \text { in two } \\
\text { rows }\end{array}$ & \begin{tabular}{|c|}
$2+2$ setae \\
in two rows \\
\end{tabular} & $?$ & $\begin{array}{c}2+2 \text { in two } \\
\text { rows }\end{array}$ & $?$ & $\begin{array}{c}2+2 \text { in two } \\
\text { rows }\end{array}$ \\
\hline $\begin{array}{l}\text { Cuticular furrow in } \\
\text { furcal rudiment }\end{array}$ & - & - & 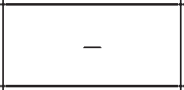 & $?$ & $\begin{array}{l}\text { "weakly } \\
\text { marked" }\end{array}$ & $?$ & + \\
\hline $\begin{array}{l}\text { Thickened sensilla on } \\
\text { Ant. IV }\end{array}$ & 0 & 2 & 2 & $?$ & $0 ?$ & $?$ & $0 ?$ \\
\hline $\begin{array}{l}\text { Position of antennal } \\
\text { organ }\end{array}$ & normal & normal & normal & $?$ & normal & $?$ & subapical \\
\hline Labium type & $A B C$ & $A B D$ & $A B D$ & $?$ & $?$ & $?$ & $A B C$ \\
\hline Dorsal pseudocelli & $\begin{array}{c}32 / 133 / \\
33343\end{array}$ & $\begin{array}{l}42 / 144 / \\
33354\end{array}$ & $\begin{array}{l}42 / 133 / \\
33354\end{array}$ & $\begin{array}{l}42 / 144 / \\
44454\end{array}$ & $\begin{array}{l}43 / 144 / \\
54453\end{array}$ & $\begin{array}{c}32 / 133 / \\
44463\end{array}$ & $\begin{array}{c}32 / 122 / \\
33343\end{array}$ \\
\hline Ventral pseudocelli & $\begin{array}{c}2 / 000 / \\
0000\end{array}$ & $\begin{array}{c}2 / 000 / \\
1111\end{array}$ & $\begin{array}{c}2 / 000 / \\
1111\end{array}$ & $\begin{array}{c}1 / 000 / \\
1112\end{array}$ & $\begin{array}{c}2 / 000 / \\
0000\end{array}$ & $?$ & $\begin{array}{c}2 / 000 / \\
1111\end{array}$ \\
\hline Subcoxal pseudocelli & 111 & 222 & 222 & 111 & 111 & 122 & 111 \\
\hline $\begin{array}{l}\text { Number of setae on } \\
\text { tibiotarsi I-III }\end{array}$ & $16,16,15$ & $14,14,13$ & $14,15,13$ & $?$ & $19,19,18$ & $19,19,18$ & $?$ \\
\hline $\begin{array}{l}\text { Number of setae in } \\
\text { distal whorl on } \\
\text { tibiotarsi }\end{array}$ & 7 & 6 & 6 & $?$ & $?$ & 10 & 11 \\
\hline $\begin{array}{l}\text { Number of setae on } \\
\text { Ant I and II }\end{array}$ & 8 and $13-14$ & 9 and 14 & 9 and 14 & $?$ & $8-9$ and 13 & $7-8$ and ? & 8 and ? \\
\hline $\begin{array}{l}\text { Arrangement of setae } \\
p 1 \text { and } p 2 \text { at posterior } \\
\text { edge of head }\end{array}$ & $\begin{array}{l}\mathrm{p} 1 \text { in front } \\
\mathrm{p} 2\end{array}$ & $\begin{array}{l}\text { at the same } \\
\text { level }\end{array}$ & $\begin{array}{c}\text { at the same } \\
\text { level }\end{array}$ & $?$ & $\begin{array}{c}\text { at the same } \\
\text { level }\end{array}$ & $?$ & $\begin{array}{c}\text { at the same } \\
\text { level }\end{array}$ \\
\hline $\begin{array}{l}\text { number of setae on } \\
\text { subcoxae I-III }\end{array}$ & $4,5,5$ & $4,3,4$ & $4,3,4$ & $?$ & $?$ & $?$ & $3,3,3$ \\
\hline microsensilla on $T h$. II & + & + & + & $?$ & + & $?$ & + \\
\hline $\begin{array}{l}\text { microsensilla on } T h \text {. } \\
\text { III }\end{array}$ & - & - & - & $?$ & + & $?$ & + \\
\hline
\end{tabular}


acters (position of antennal organ and chaetotaxy of tibiotarsus, among them). The differentiating characters of M. stojkoae sp.n. and other new species are given in Table.

NAME DERIVATION. The species is named after the master of the first author of the publication, Tamara Stojko, a naturalist and a teacher of Penza State Pedagogical University.

DISTRIBUTION. Known from three districts located in forest-steppe zone of European part of Russia.

\section{Oligaphorura kremenitsai Shvejonkova et Potapov, sp.n.} Figs 12-19.

TYPE MATERIAL: Holotype: $\sigma^{7}$, Russia (Caucasus), Adygeya Republic, interfluve of Belaya River and Pshekha River, Lagonaki Plateau, $1800 \mathrm{~m}$ alt., soil $(15-20 \mathrm{~cm}$ depth), 7.IX.2007, leg. A. Kremenitsa. Paratypes: 2 specimens, ibidem.

DESCRIPTION. Length of body $0.5-0.6 \mathrm{~mm}$. Body of normal shape, without anal spines. Length of antennae as about 5/6 of head. Furcal rudiment appears field with thinner granulation with $2+2$ setae in two rows behind, without cuticular furrow. Granulation of body regular, coarser around dorsal pso, each pso with 12-14 granules.
Ant. IV with subapical organite. Two sensilla, dorso-subapical and inner-subbasal, on Ant. IV thicker than others (Fig. 15). Lateral $m s$ above antennal organ III, in first row of setae. Antennal organ III in normal position, with 5 papillae, 2 sensory rods, 2 clubs (external large, with wrinkles, internal smaller, granulated), 5 guard setae (Fig. 16). Ms of Ant. III in lateral position, under antennal organ. Ant. I and II with 9 and 14 setae, respectively. Labial palp as in $O$. humicola sp.n., with 5-6 proximal setae, of $A B D$ type (Fig. 17). Maxillary palp simple, two sublobal hairs. PAO small, with three-lobed vesicle.

Pseudocellar formula dorsally 42/144/33354, ventrally 2/000/1111. On $A b d$. I ventral pso in lateral position. Parapseudocelli indistinct. Each subcoxa with 2 pso.

Chaetotaxy poorly differentiated to macro- and microsetae (Figs 12-13). Dorsal sensilla normally well developed, with formal formula from $2 / 022 / 33212$ to $2 / 022 / 22110$. The development of dorso-lateral sensilla on $\mathrm{Abd}$. I-IV and dorsal sensilla on $A b d$. V vary depending on the specimen, sometimes they appear slightly thickened setae. Ventral formula of sensilla 2/000/0011. With $0,0,1$ sensilla on lower subcoxa. On head seta $d 0$ absent, in posterior row of setae $p 1$ at the level with $p 2$. On $T h$. II $-A b d$.

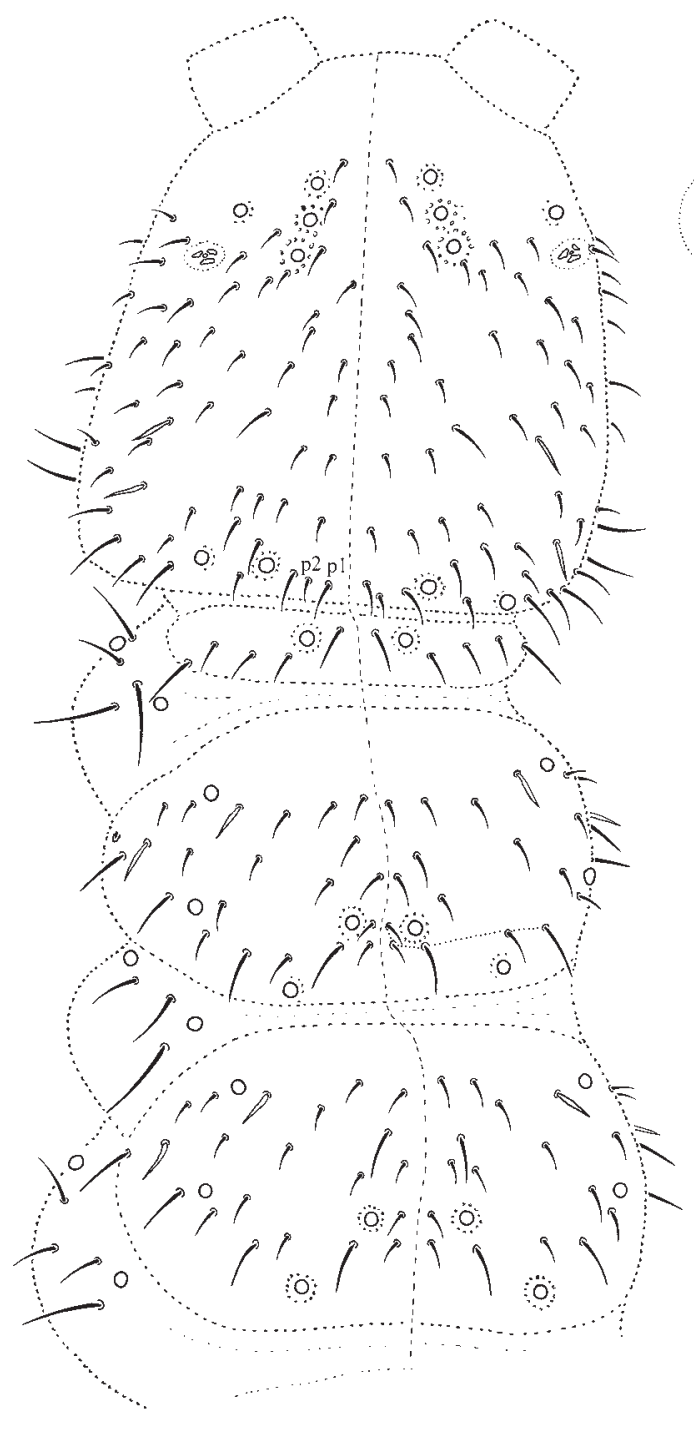

12

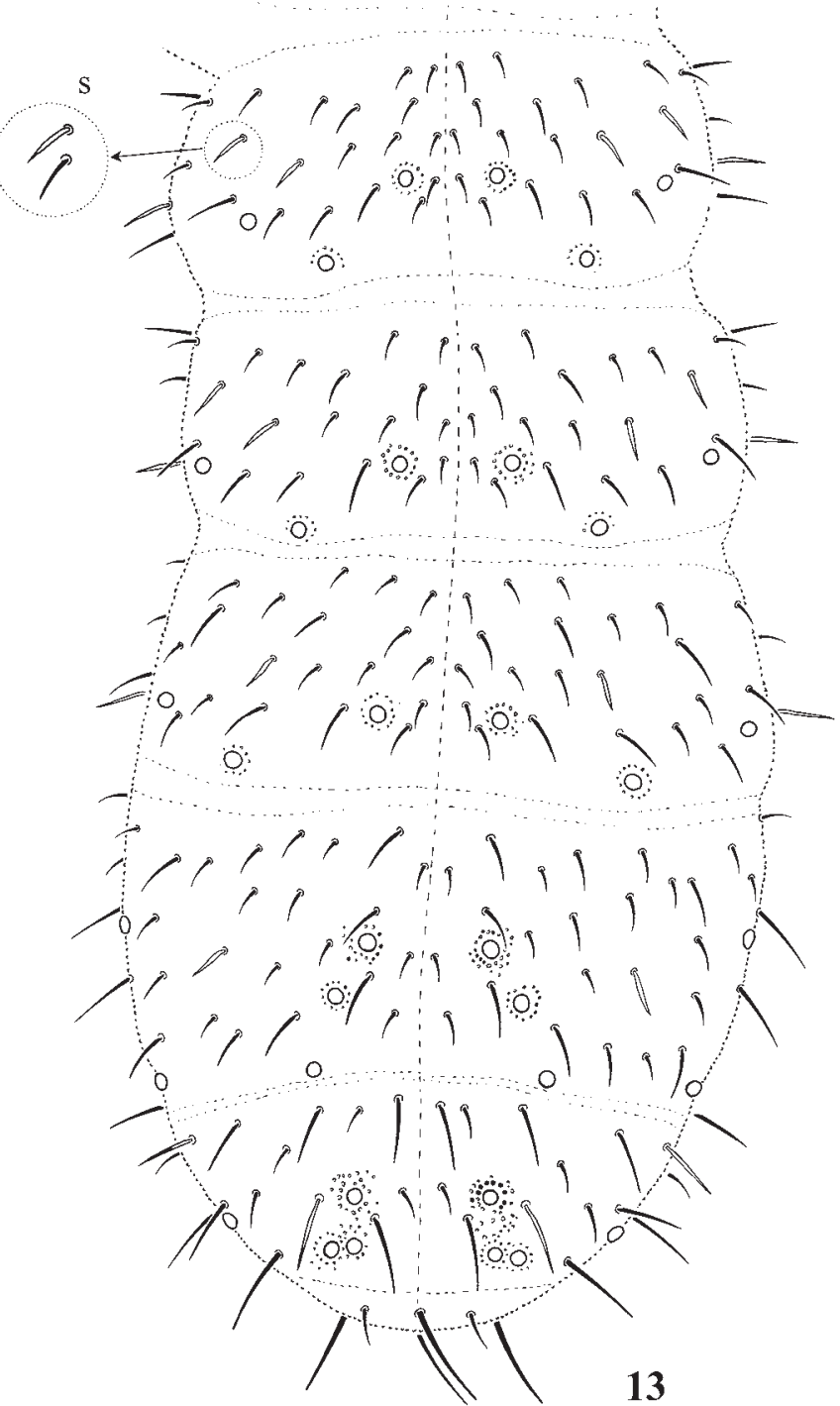

13

Figs 12-13. Oligaphorura kremenitsai sp.n., dorsal chaetotaxy: 12 - head and thorax; 13 - abdomen.

Рис. 12-13. Oligaphorura kremenitsai sp.n., хетотаксия дорсальной поверхности: 12 — голова и грудь; 13 - брюшко. 
III seta $p 1$ in front of $p 2$. On $A b d$. VI $a 0$ subequal to $a 2, a 11 / 3$ as long as $a 0$. Lateral $m s$ present only on Th. II. Subcoxa I, II, III with 4, 3, 4 setae, respectively. Ventral chaetotaxy as shown in Figs 14, 18-19. Furca reduced to finely granulated areas with $2+2$ "dental" setae arranged in two transversal rows, with only one row of manubrial setae in median area (Fig. 18). Ventral tube with $6+6$ setae and $2+2$ setae at its base. Thoracic sternites II and III with $1+1$ setae each.

Claw without teeth, empodial appendage with weak basal lamella, about half as long as inner edge of claw. Chaetotaxy of tibiotarsi as in O. humicola sp.n. I, II, III with 14, 14(15), 13 setae, respectively, with 6 ones in distal whorls. Seta Y' usually absent (see the description of $O$. humicola sp.n.)
Males present, without ventral organ.

DISCUSSION. New species resembles $A$. marcuzzii (Cassagnau, 1968) (Italian Alps). They share the absence of anal spines and two exceptional characters rarely occur in the tribe: 4 antennal pso and 4 pso on each side of Th. II and III. $O$. kremenitsai sp.n. differs from $A$. marcuzzii by the total number of dorsal and ventral pso (42/144/33354; 2/000/1111 vs. 42/ $144 / 44454 ; 1 / 000 / 1112$, respectively). Among spined species, both characters mentioned above are known in Oligaphorura montana Weiner, 1994 (North Korea), the former character in Oligaphorura kurtshevae (Martynova, 1981) (Far East of Russia). Other aspined species of Oligaphorurini, A. alavensis Simón et Luciáñez, 1994 and $A$. serratotuberculata differ from

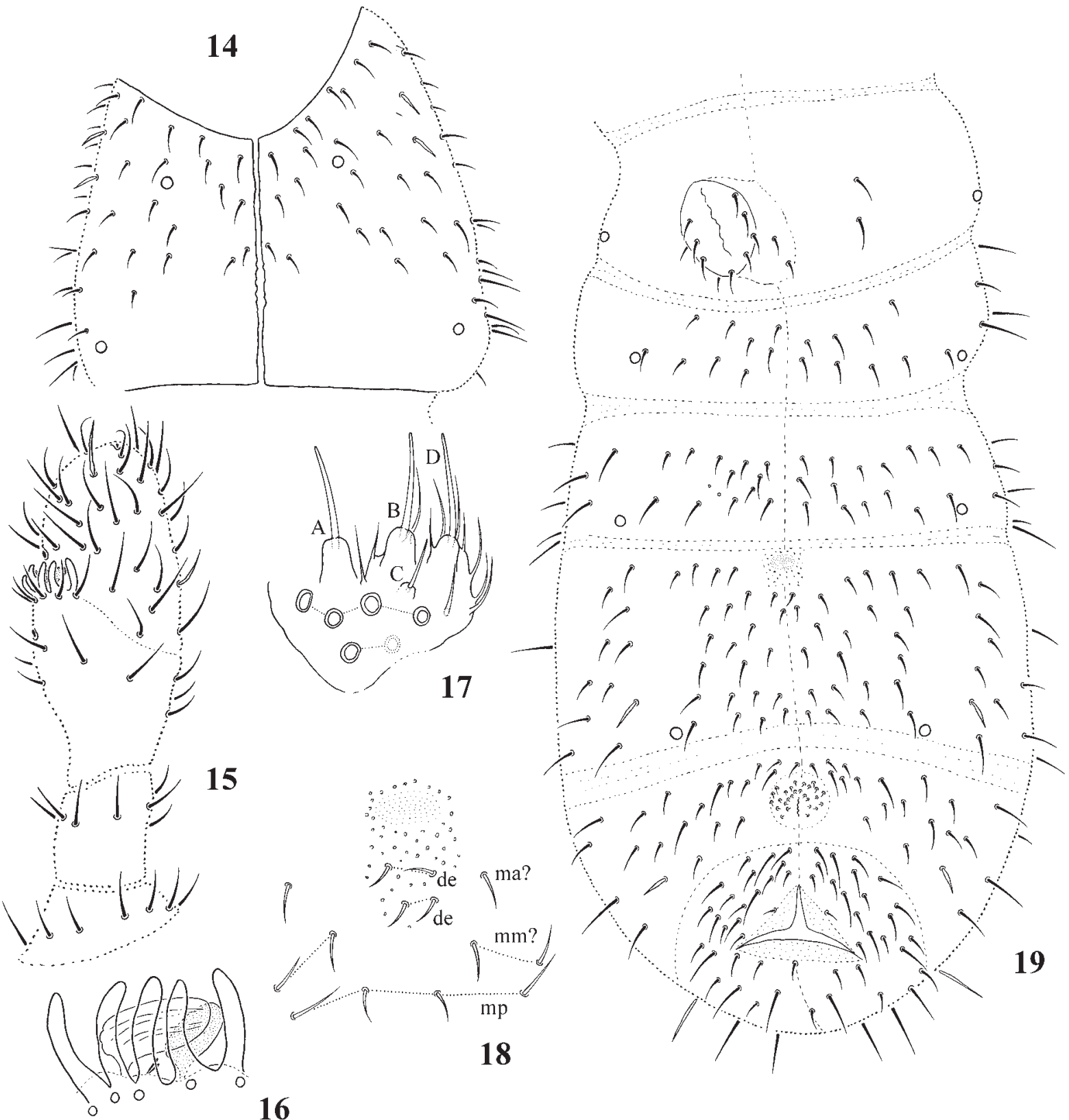

Figs 14-19. Oligaphorura kremenitsai sp.n.: 14 - ventral chaetotaxy of head; 15 - antenna, dorsal view; 16 - antennal organ; 17 labial palp; 18 - furcal area; 19 - ventral chaetotaxy of abdomen. Abbreviations as in Figs 3-11.

Рис. 14-19. Oligaphorura kremenitsai sp.n.: 14 - хетотаксия вентральной поверхности головы; 15 - усик, вид со спинной поверхности; 16 - антеннальный орган; 17 - нижнегубной щупик; 18 - поле прыгательной вилки; 19 - хетотаксия брюшной поверхности брюшка. Условные обозначения как на рис. 3-11. 
O. kremenitsai sp.n. at least by pseudocellar formula and by the number of setae on tibiotarsi $(19,19,18$ versus $14,14,13)$.

NAME DERIVATION. The species is named after tireless explorer of Caucasian Collembola, our friend and colleague, Alexander Kremenitsa.

DISTRIBUTION. Known only from type locality.

Oligaphorura humicola Shvejonkova et Potapov, sp.n. Figs 20-30.

TYPE MATERIAL. Holotype: $\sigma^{\top}$, Russia (S European part), Kursk district, Streletskiy plot of "Kurskiy" Reserve, meadow steppe, soil $(15-40 \mathrm{~cm}), 9 . V .2008$, leg. M. Potapov. Paratypes: $\sigma^{7} \sigma^{7}$ and +, same label; $2 \sigma^{\top} \sigma^{7}$, ibidem, soil $(0-50 \mathrm{~cm}), 24$.VII.2009, leg. A.Gomina-Bogdanova.

OTHER MATERIAL: 5 specimens, Russia (European part), Penza district, near Zarechniy, deciduous forest (aspen and birch), 04.VI.2009, leg. T. Razzhivina.

DESCRIPTION. Length of body about $0.5 \mathrm{~mm}$. Body of normal shape, without anal spines. Antennae about as long as head. Furcal rudiment appears field with thinner granulation with $2+2$ setae behind, without cuticular furrow. Granulation of body regular, coarser around dorsal pso, each pso with 12-13 granules. Ant. IV with subapical organite (Fig. 27). Two sensilla, dorso-subapical and inner-subbasal, on Ant. IV thicker than others. Lateral $m s$ above antennal organ III, in first row of setae. Antennal organ III in normal position, with 5 papillae, 2 sensory rods, 2 clubs, and 5 guard setae (Figs 26). Ms of Ant. III in lateral position, under antennal organ. Ant. I and II with 9 and 14 setae, respectively. Labial palp with 6 (rarely 5) proximal setae, 10 guards (6 middle-sized and 4 smaller), terminal sensilla of papillae $A, B$ and $D$ thickened ( $A B D$ type), sensillum $C$ weak, papilla $E$ undeveloped, associated sensillum possibly present but undistinguished from lateral guards (Fig. 28). Maxillary palp simple, two sublobal hairs. PAO small, with three-lobed vesicle.

Pseudocellar formula dorsally 42/133/33354 (Figs 20-21), ventrally 2/000/11110 (Fig. 29). On $A b d$. I ventral pso in lateral position. Parapseudocelli undeveloped. Each subcoxa with 2 pso.

Chaetotaxy shown in Figs 20-21, poorly differentiated to macro- and microsetae. Sensilla distinct, their formal number varies from $2 / 022 / 32212$ to $2 / 022 / 22110$ depending on "sensillarization" of $A b d$. I, III, and V. Ventral formula of sensilla
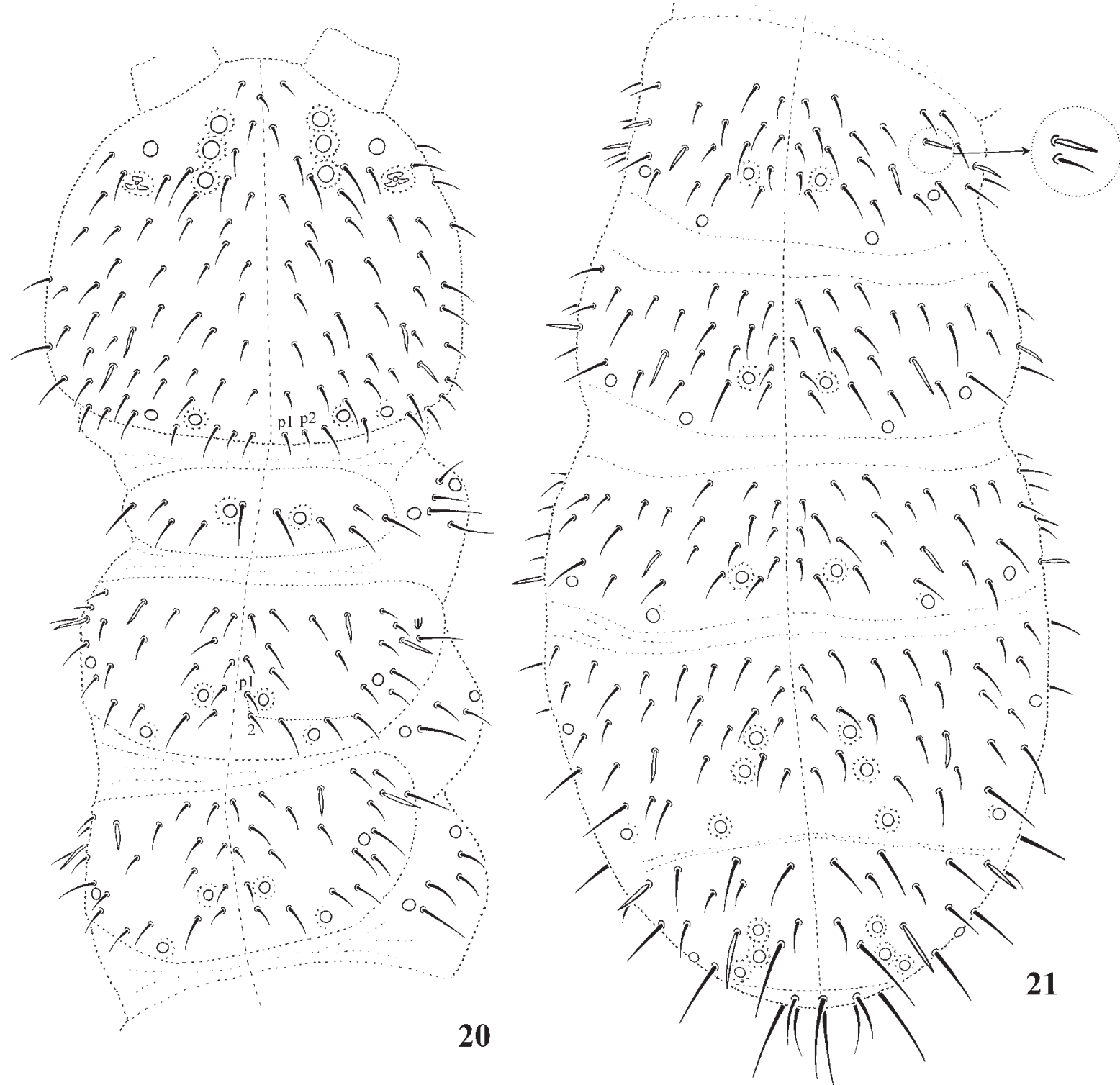

Figs 20-21. Oligaphorura humicola sp.n., dorsal chaetotaxy: 20 - head and thorax; 21 - abdomen.

Рис. 20-21. Oligaphorura humicola sp.n., хетотаксия дорсальной поверхности: 20 — голова и грудь; 21 - брюшко. 
2/000/000101 (Fig. 29).With 0, 0, 1 sensilla on lower subcoxa. On head seta $d 0$ absent, in posterior row of setae $p 1$ at the level with $p 2$. On $T h$. II $-A b d$. III seta $p 1$ in front of $p 2$. On $A b d$. VI $a 0$ subequal to $a 2, a 1$ half as long as $a 0$. Lateral $m s$ present only on Th. II. Subcoxa I - III with 4, 3, 4 setae, respectively. Ventral chaetotaxy shown in Figs 22, 29. Furca reduced to finely granulated areas with $2+2$ dental setae arranged in two transversal rows (Fig. 29-30). Ventral tube with $6+6$ setae and $2+2$ setae at
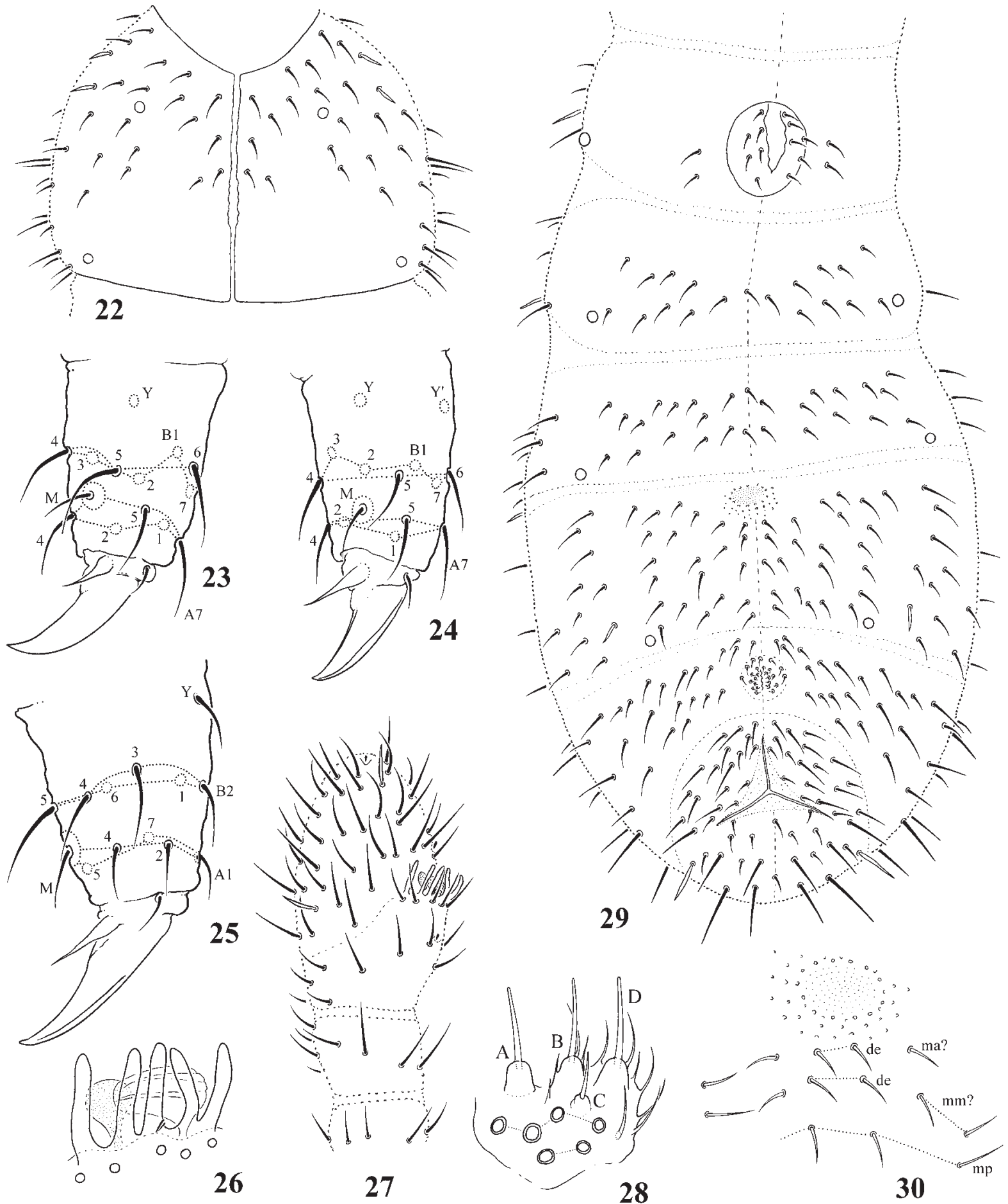

Figs 22-30. Oligaphorura humicola sp.n.: 22 - ventral chaetotaxy of head; $23-25$ - tibiotarsi of leg I (23), II (24), and III (25); 26 antennal organ; 27 - antenna, dorsal view; 28 - labial palp (proximal setae shown as sockets); 29 - ventral chaetotaxy of abdomen; 30 - furcal area. Abbreviations as in Figs 3-11.

Рис. 22-30. Oligaphorura humicola sp.n.: 22 - хетотаксия вентральной поверхности головы; 23-25 - тибиотарзусы первой (23), второй (24) и третьей (25) пар ног; 26 - антеннальный орган; 27 - усик, вид со спинной поверхности; 28 - нижнегубной щупик (проксимальные щетинки показаны в виде оснований); 29 - хетотаксия вентральной поверхности брюшка; 30 — поле прыгательной вилки. Условные обозначения как на рис. 3-11. 


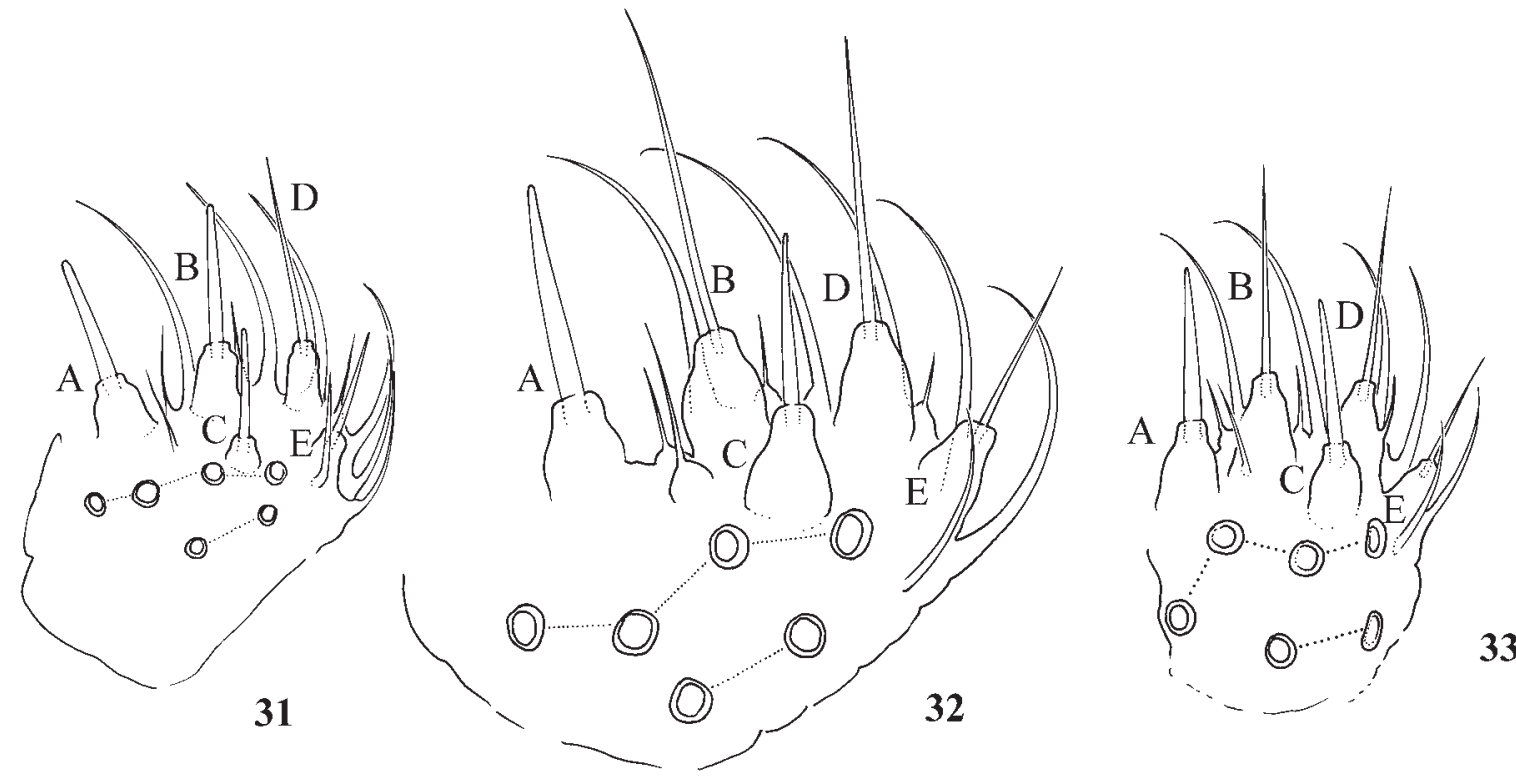

Figs 31-33. Labial palp: 31 - Archaphorura complex serratotuberculata (Moscow district); 32 - Oligaphorura groenlandica (Arctic: Severnaya Zemlya Archipelago); 33 - Micraphorura absoloni (Smolemsk district); A, B, C, D, E- papillae of labial palp.

Рис. 31-33. Нижнегубной щупик: 31 - Archaphorura complex serratotuberculata (Московская область); 32 - Oligaphorura groenlandica (архипелаг Северная Земля); 33 - Micraphorura absoloni (Смоленская область); $A, B, C, D, E$ - выросты нижнегубного щупика.

base. Thoracic sternites II and III with $1+1$ setae each.

Claw without teeth, empodial appendage with weak basal lamella, about $2 / 3$ as long as inner edge of claw. Tibiotarsi I, II, III with 14, 15(14), 13 setae, respectively, with 6 ones in distal whorls. Strong reduction of number of setae partly masks homology of setae, in our understanding $A$ row with 5 setae $(A 1, A 2, A 4, A 5, A 7), B$ row with 7 setae $(B 1-7)$, seta $B 7$ on leg III absent, $T$-setae absent, $M$ seta present on all legs and incorporated to distal whorl. Seta $Y$ present on all legs, tibiotasus of leg II usually have two seta in proximal whorl: $Y$ and extra seta $Y^{\prime}$ (Figs 23-25).

Males present, without ventral organ.

DISCUSSION. The species shares many characters with Oligaphorura kremenitsai sp.n. and differs in fewer pseudocelli. Similarity of their labial palps, chaetotaxy of furcal area, and uncommon tibiotarsal chaetotaxy is of particular importance. Both Archaphorura (Arcaphorura: sic!) alavensis (Spain) and A. serratotuberculata has only 3 antennal pso (4 in O. humicola sp.n.).

NAME DERIVATION. In type locality the species inhabits deep soil layers of chernozem.

DISTRIBUTION. Two localities in forest-steppe and steppe zones of European part of Russia.

ACKNOWLEDGEMENTS. The present study has been supported by Russian Foundation for the Basic Research (Project \# 08-04-00887a). We much indebted to our colleagues for the material they collected or loan for us: A. Gomina, A. Kremenitsa, N. Kuznetsova, T. Razzhivina, V. Romanov. We would like to express our sincere thanks to A. Babenko (Moscow) for his friendly and fruitful comments and I. Kaprus (L'viv) who shared some information on his new species.

\section{References}

Babenko A.B., Chimitova A.B. \& Stebaeva S.K. 2011. New Palaearctic species of the tribe Thalassaphorurini Pomorski,
1998 (Collembola: Onychiuridae) // Zookeys. Vol.126. P.138 .

Bagnall R.S. 1948. Contributions toward a knowledge of the Onychiuridae (Collembola-Onychiuroidea). I-IV // Ann. Mag. Nat. Hist. Vol.11. P.631-642.

Bagnall R.S. 1949. Contributions toward a knowledge of the Onychiuridae (Collembola-Onychiuroidea). V-X // Ann. Mag. Nat. Hist. Vol.12. P.498-511.

Fjellberg A. 1998. The Collembola of Fennoscandia and Denmark. Part. I: Poduromorpha // Fauna Entomol. Scand. Vol.35. 183 pp.

Fjellberg A. 1998/99. Labial Palp in Collembola // Zool. Anz. Bd.237. S.309-330.

Fjellberg A. \& Potapov M. 1998. A redefinition of Blissia with description of a new species from northwestern Canada (Collembola: Isotomidae) // Eur. J. Entomol. Vol.95. P.87-91.

Pomorski R.J. 1996. The first instar larvae of Onychiurinae - a systematic study (Collembola: Onychiuridae) // Genus. Vol.7. No.1. P.1-102.

Pomorski R.J. 1998. Onychiurinae of Poland // Genus (Suppl.). 201 pp. Pomorski R.J. 2006. Review of the genus Vibronychiurus (Collembola: Onychiuridae), with a description of two new species // Eur. J. Entomol. Vol.103. P.673-677.

Pomorski R.J. \& Sveenkova Yu.B. 2006. New genus with three new species of Thalassaphorurini (Collembola: Onychiuridae) from Russian Far East // Insect Syst. Evol. Vol.37. P.191-196.

Potapov M., Babenko A. \& Fjellberg A. 2006. Taxonomy of the Proisotoma complex. Redefinition of genera and description of new species of Scutisotoma and Weberacantha (Collembola, Isotomidae) // Zootaxa. No.1382. P.1-74.

Potapov M.B., Bu Y., Huang C.-W., Gao Y. \& Luan Y.X. 2010 Generic switch-over during ontogenesis in Dimorphacanthella gen. n. (Collembola, Isotomidae) with barcoding evidence // Zookeys. Vol.73. P.13-23.

Stach J. 1933. Dwa nowe gatunki rodzaju Onychiurus Gerv. z Polski // Bull Acad. Polon. Sc. Sér.B. II. P.235-243.

Weiner W.M. 1996. Generic revision of Onychiurinae (Onychiuridae, Collembola) with a cladistic analysis // Ann. Soc. Entomol. Fr. (N.S.). T.32 . Fasc.2. P.163-200.

Sun X., Chen J.-X. \& Deharveng L. 2010. Six new species of Thalassaphorura (Collembola, Onychiuridae) from southern China, with a key to world species of the genus // Zootaxa. No.2627. P.20-38. 